\title{
KESIAPAN MAHASISWA JURUSAN PENDIDIKAN ADMINSTRASI PERKANTORAN DALAM KOMPETISI PASAR KERJA DI ERA MEA
}

\author{
Indri Murniawaty $^{1}$ Wisudani Rahmaningtyas $^{2}$ \\ Jurusan Pendidikan ekonomi Fakultas Ekonomi Universitas Negeri Semarang \\ indrimurniawaty@mail.unnes.ac.id ${ }^{1}$ wisudani.rahmaningtyas@ mail.unnes.ac.id ${ }^{2}$
}

\begin{abstract}
Nowadays, competence mastery is highly required in order to compete in the ASEAN Economic Community (AEC) Era. The purpose of this research is to figure out the students' understanding and readiness dealing with the ASEAN Economic Community as well as the possible encountering problems when competing in the ASEAN Economic Community Era. This research uses a descriptive-qualitative approach conducted at Economics Faculty involving respondents of office administration education department students in the academic year of 2014/2015. The data are collected through questionnaires. The research results show that based on the aspect of communication competence, students are adequately ready with the percentage of $71.46 \%$; based on the aspect of capability competence, they are categorized into high by $64.72 \%$; and their knowledge competence has already reached $73.14 \%$.
\end{abstract}

Keywords: Labor markets in the ASEAN Economic Community (AEC) Era, Students' readiness, Working competence,

PENDAHULUAN

Masyarakat Ekonomi ASEAN

(MEA) merupakan bentuk kesepakatan yang disepakati oleh negara-negara yang tergabung dalam wilayah ASEAN. Masyarakat Ekonomi ASEAN sendiri telah diresmikan sejak 31 Desember 2015. Negara-negara ASEAN yang tergabung dalam kesepakan tersebut adalah terdiri dari 10 negara yaitu Indonesia, Malaysia, Filipina, Singapura, Thailand, Brunei Darussalam, Vietnam, Laos, Myanmar, dan Kamboja. Negara-negara tersebut sepakat untuk melakukan kerjasama dibidang perekonomian, melalui dibukanya lahan-lahan perdagangan bebas dikawasan ASEAN. Tujuan dibentuknya MEA 2015 adalah menciptakan stabilitas perekonomian masing-masing negara anggota dari MEA dan mengatasi masalahmasalah perekonomian negara. Yang diterjemahkan dalam empat pilar utama yaitu ASEAN sebagai pasar tunggal dan basis produksi internasional (single market and production base), kawasan dengan daya saing ekonomi yang tinggi (competitive economic region), kawasan dengan pengembangan ekonomi yang merata (equitable economic development) 
dan sebagai kawasan yang terintegrasi secara penuh dengan perekonomian global (integration into the global economy). Mahasiswa dikenal masyarakat luas sebagai kaum yang cerdas dan kreatif, punya keberanian serta kegigihan. Selain itu mahasiswa dipandang sebagai kaum intelektual dengan ambisi yang besar, mampu berpikir kritis dan peka terhadap perubahan lingkungan. Kompetensi mahasiswa terkait dengan disiplin ilmu yang diambil tentunya menjadi hal yang wajar, jika seorang mahasiswa perkantoran pandai mengelola kantor adalah hal biasa. Namun apabila mahasiswa perkantoran punya ketrampilan bahasa asing, soft skill dan hard skill merupakan hal yang luar biasa. Sebagai kaum yang dianggap cerdas oleh masyarakat, tentunya mahasiswa mempunya tanggungjawab terhadap dirinya sendiri dan juga orang lain. Paradigma masyarakat terkadang mengaitkan mahasiswa adalah orang yang bisa banyak hal dan menguasai berbagai keilmuan. Dari paradigma tersebut seorang mahasiswa menjadi agent social of control. Menganalisis dari keadaan sekarang ini, seorang mahasiswa harus dinamis dalam menghadapi perubahan dan perkembangan lingkungan. Oleh karena itu, mahasiswa harus menjadi pribadi yang cerdas, kritis, dinamis dan berempati dalam menghadapi persaingan (Tiwi. 2010).

Mahasiswa harus melihat MEA sebagai peluang yang terbuka untuk memperbaiki kualitas terkait dengan berbagai kompetensi yang ada untuk meningkatkan daya saing, dengan cara mengikuti perkembangan keilmuan, keterampilan baik soft skill maupun hardskill. Mahasiswa harus kritis dan dinamis terhadap perubahan lingkungan yang nantinya akan digeluti. Penguasaan kompetensi menjadi hal positif dan sangat penting dalam peningkatan keahlian tidak hanya terkait dengan keilmuan yang ditekuni. Hal ini menjadi tantangan sekaligus ancaman bagi mahasiswa, tergantung bagaimana mahasiswa mampu mengelola dirinya untuk bisa bersaing atau berkompetisi di era MEA.

Dibutuhkan persiapan matang, yang harus disiapkan dan ditempuh oleh mahasiswa terkait dengan kondisi mahasiswa ketika lulus dan harus berkompetisi dalam mencari pekerjaan maupun dalam melakukan pekerjaan. Tidak semata berbekal kecerdasan secara intelektual namun juga kecerdasan emosional, spiritual, kemampuan berbahasa asing dan pengelolaan IT. Kompetensi mahasiswa lulus dan siap untuk menghadapi MEA bukan hanya kompetensi akademik (intelektual) saja yang dibutuhkan. Karena 
persaingan yang sangat terbuka akan hadir di MEA dalam ajang mencari sumber daya manusia yang mempunyai kualifikasi dan sertifikasi keahlian tertentu. Maka lulusan perguruan tinggi harus benar-benar memberikan outcome dalam memenuhi harapan dalam dunia MEA nantinya.

Melihat realita yang ada di lapangan, maka diperlukan suatu kajian tentang persiapan mahasiswa jurusan pendidikan administrasi perkantoran dalam kompetisi pasar kerja di era MEA.

\section{KAJIAN PUSTAKA}

\section{Kesiapan Kerja}

Berdasarkan pendapat Herminanto (Sofyan.1992:10) menyatakan bahwa, "Kesiapan Kerja adalah suatu kemampuan seseorang untuk menyelesaikan suatu pekerjaan sesuai dengan ketentuan, tanpa mengalami kesulitan, hambatan dengan hasil maksimal dengan target yang telah ditentukan". Sedangkan menurut UU No.13 tahun 2003 tentang ketenagakerjaan Kesiapan Kerja adalah "Kemampuan kerja setiap individu yang mencakup aspek pengetahuan, keterampilan dan sikap kerja yang sesuai dengan standar yang diterapkan."

Aspek-aspek yang mempengaruhi kesiapan seseorang meliputi kemampuan intelegensi, kemauan, bakat, hobi, motivasi, sikap, kepribadian, nilai, prestasi, keterampilan, penggunaan atau pemanfaatan waktu luang, Aspirasi dan pengetahuan sekolah atau pendidikan sambungan, pengetahuan tentang dunia kerja, pengalaman kerja, masalah keterbatasan pribadi baik fisik maupun lahiriah dan juga dipengaruhi oleh faktor sosial.

Seseorang siap atau tidak bisa dilihat dari beberapa aspek selain aspek yang telah disebutkan yaitu mempunyai ambisi untuk maju dan berusaha mengikuti perkembangan bidang keahlian, mempunyai kemampuan beradaptasi dengan lingkungan dan perkembangan teknologi, mempunyai keberanian untuk menerima tanggung jawab secara individual, bekerja diperlukan tanggung jawab dari setiap para pekerja, keberanian untuk menerima tanggung jawab secara individual, dalam bekerja diperlukan tanggung jawab dari setiap para pekerja, kritis dan logis.

\section{MEA}

MEA adalah komunitas ASEAN (ASEAN Community) di bidang Ekonomi atau ASEAN Economic Community (AEC) yang dicanangkan pada Konferensi Tingkat Tinggi (KTT) ASEAN ke-9 di Bali pada tahun 2003, atau dikenal sebagai Bali Concord II. Pembentukan komunitas tersebut diprakarsai oleh para Kepala Negara ASEAN pasca krisis ekonomi JURNAL PROMOSI | 19 
tahun 1997 di kawasan Asia Tenggara. MEA diharapkan dapat mewujudkan tercapainya suatu kawasan stabil, makmur, berdaya saing tinggi dengan pertumbuhan ekonomi yang berimbang serta berkurangnya kemiskinan dan kesenjangan sosial ekonomi.Bali Concord II tidak hanya menyepakati pembentukan MEA, namun juga menyepakati pembentukan komunitas ASEAN di bidang Keamanan Politik (ASEAN Political-Security Community) dan Sosial Budaya (ASEAN Socio- CultureCommunity). (Syukriyah. 2013)

Pembentukan ASEAN Economic Community disepakati dibentuk pada 2015 yang implementasinya mengacu pada ASEAN Econommic Community (AEC) Blueprint. AEC Blueprint memuat empat pilar yaitu:

1) ASEAN sebagai pasar tunggal dan berbasis produksi tunggal yang didukung dengan elemen aliran bebas barang, jasa, investasi, tenaga kerja terdidik, dan aliran modal yang lebih bebas.

2) ASEAN sebagai kawasan dengan daya saing ekonomi tinggi, dengan elemen peraturan kompetisi, perlindungan konsumen, hak atas kekayaan intelektual, pengembangan infrastruktur, perpajakan, dan $e$ commerce.
3) ASEAN sebagai kawasan dengan pengembangan ekonomi yang merata dengan elemen pengembangan usaha kecil dan menengah dan prakarsa integrasi ASEAN untuk negaranegara CMLV (Cambodja, Myanmar, Laos, danVietnam).

4) ASEAN sebagai kawasan yang terintegrasi secara penuh dengan perekonomian global dengan elemen pendekatan yang koheren dalam hubungan ekonomi di luar kawasan, dan meningkatkan peran serta dalam jejaring produksi global.

\section{Kompetensi yang harus dimiliki} menjelang MEA

a. Communication Competency

Kompetensi berkomunikasi merupakan salah satu kompetensi yang dimiliki oleh seorang mahasiswa agar dapat bersaing di era MEA. Kemampuan berkomunikasi merupakan kemampuan dasar seseorang untuk dapat berinteraksi dengan orang lain. Communication competency ini terbagi menjadi dua, yaitu komunikasi interpersonal dan komunikasi intrapersonal. Kemampuan komunikasi interpersonal merupakan Komunikasi yang 
berhubungan dengan komunikasi antarmanusia. Sedangkan komunikasi intrapersonal merupakan komunikasi dengan dirinya sendiri, merencanakan hidup dan mendorong diri sendiri untuk bertindak atau dengan kata lain proses kognitif yang berlangsung dalam diri kita.

b. Capability Competency

Capability competency merupakan kompetensi yang harus dimiliki mahasiswa untuk dapat bersaing di era MEA. Kompetensi ini merupakan kompetensi penunjang keahlian seperti kemampuan bahasa asing (bahasa Inggris, Mandari dll), kemampuan tekhnologi dan kemampuan softskill dan hardskill lainnya.

c. Knowledge Competency

Kompetensi ini merupakan pengetahuan mahasiswa terhadap keadaan yang akan dihadapinya, dimana pada penelitian ini dibatasi dengan pengetahuan mengenai MEA.

Kerangka kompetensi yang harus disiapkan untuk menghadapi MEA, digambarkan dalam bagan berikut: 


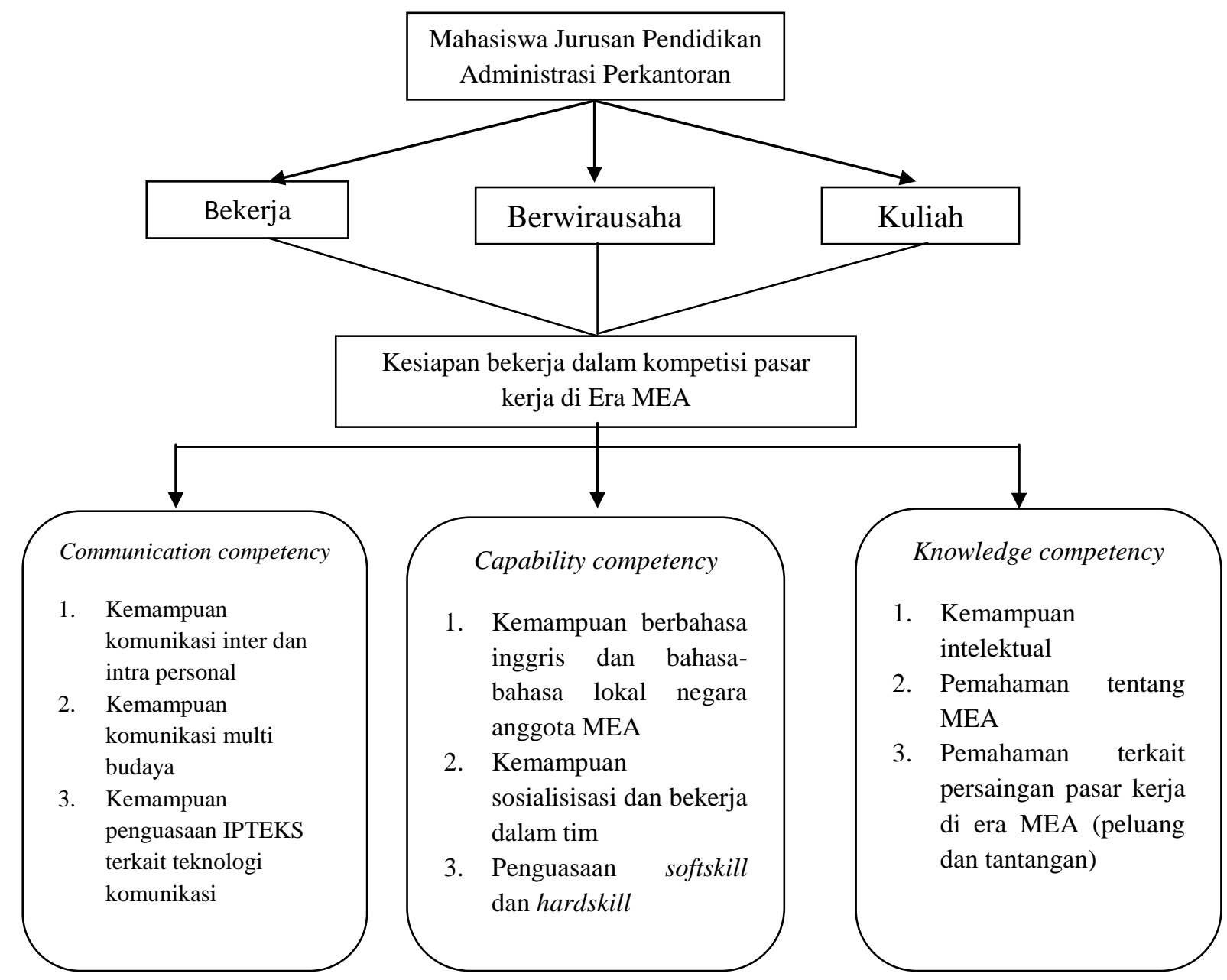

\section{METODE PENELITIAN}

Penelitian ini dilaksanakan di Jurusan Pendidikan Administrasi Perkantoran, Pendidikan Ekonomi, Fakultas Ekonomi, Universitas Negeri Semarang. Populasi Penelitian ini adalah 54 Mahasiswa Jurusan Pendidikan Administrasi Perkantoran Angkatan 2014. Berdasarkan tujuan penelitian, perubah yang diamati/diukur dalam penelitian ini adalah kesiapan mahasiswa jurusan pendidikan administrasi perkantoran dalam kompetisi pasar kerja di era MEA. Pendekatan penelitian ini adalah deskriptif kuantitatif. Teknik pengumpulan data menggunakan angket semi terbuka. Dan analisis data pada penelitian ini menggunakan analisis deskriptif presentase.

\section{PEMBAHASAN HASIL PENELITIAN}

Dari hasil gambaran penelitian diketahui bahwa tingkat communication competency mahasiswa untuk menghadapi MEA berada pada kategori, yang dinilai dari tiga kompetensi, yaitu :

\section{Communication Competency}

Dari hasil penelitian terungkap bahwa 71.64\% mahasiswa Jurusan Pendidikan 
Administrasi perkantoran sudah mempunyai communication competency tinggi. Indikator kompetensi komunikasi ini meliputi kemampuan komunikasi interpersonal dan intrapersonal, komunikasi multi budaya dan penguasaan IPTEK. Hal tersebut dibuktikan dengan $83,36 \%$ sampel menjawab setuju pada item "Saya memiliki kemampuan komunikasi interpersonal dan intrapersonal yang baik."

Bukti kesiapan ini juga didukung dengan pernyataan sangat setuju sebesar $55.56 \%$ pernyataan "Saya terbuka dalam menjalin hubungan pertemanan dengan siapapun”. Dari hasil tersebut menggambarkan bahwa mahasiswa sudah mempunyai keterampilan interpersonal dan intrapersonal dengan baik. Hal ini sangat penting untuk mempersiapkan menghadapi MEA. Secara teori kemampuan komunikasi merupakan kemampuan softskill yang harus dimiliki oleh setiap orang. Mahasiswa sebagai calon yang akan bekerja haruslah mempunyai keterampilan softskill berkomunikasi. Sesuai dengan yang dikemukakan oleh Dewa Ketut dalam Tri Hartati (2016:13) bahwa faktor yang berpengaruh terhadap kesiapan kerja individu adalah keterampilan.Dalam dunia kerja sumber daya manusia yang unggul adalah mereka yang tidak hanya memiliki keterampilan hardskill tapi juga softskill.
Komunikasi sendiri merupakan kemampuan softskill. Melalui komunikasi dapat tercipta hubungan yang harmonis dalam dunia kerja. Para ahli komunikasi bahkan mengutarakan bahwa komunikasi mempelajari bagaimana komunikasi menciptakan dan mempertahankan hubungan dan bagaimana pasangan berkomunikasi untuk mengatasi tantangan normal dan luar biasa dalam mempertahankan keintiman sepanjang waktu.

Hal senada juga dikemukakan oleh Fitriyanto (2006:9) bahwa salah satu cirri dari peserta didik yang sudah mempunyai kesiapan kerja adalah mempunyai kemampuan dan kemauan untuk bekerja sama dengan orang lain, tidak menutup diri, terbuka menjalin kerjasama dan mampu berinteraksi dengan orang lain. Tenaga kerja yang mempunyai keterampilan berkomunikasi ini akan mampu bekerja sama, bertanggung jawab, mempunyai kepercayaan diri. Dihadapkan dengan MEA, maka keterampilan komunikasi ini akan sangat mendasar menjadi kebutuhan mendasar bagi tenaga kerja.

Hal lain yang membuktikan bahwa mahasiswa Prodi Administrasi Perkantoran sudah siap dalam menghadapi persaingan kerja MEA adalah ditinjau dari sikap mahasiswa yang telah mempunyai sikap 
untuk dapat memutuskan tentang sesuatu yang akan berpengaruh terhadap kehidupannya dimasa mendatang. Sebanyak 62,96\% mahasiswa menyatakan tidak setuju terhadap pernyataan "Saya mudah terpengaruh budaya yang berkembang di lingkungan sehari-hari saya" Menurut Dewa Ketut dalam Tri Hartati (2016:13) bahwa salah satu faktor yang dapat berpengaruh terhadap kesiapan kerja adalah sikap. Sikap dapat mendorong seseorang untuk bertindak secara tertentu terhadap hal-hal tertentu, dan ini juga memberikan pengaruh terhadap seseorang untuk mengambil tindakan yang berhubungan dengan karir atau pekerjaan seseorang di masa mendatang.

\section{Capability competency}

Sebesar 64,72\% mahasiswa Untuk Jurusan Pendidikan Administraasi Perkantoran sudah mempunyai capability competency. Indikator kompetensi ini adalah kemampuan berbahasa asing (bahasa Inggris dan lain-lain), kemampuan bersosialisasi dan bekerja dalam team serta penguasaan softskill dan hardskill. Terdapat sebanyak 38 mahasiswa atau $70,37 \%$ dari sampel yang menyatakan setuju pada item nomor lima, bahwa "Saya mampu melakukan negoisasi dalam kehidupan sehari-hari" dan pada item nomor enam dan tujuh masing-masing sebanyak 34 mahasiswa atau 62,96\% menyatakan setuju pada pernyataan bahwa "Saya mampu mempengaruhi orang lain untuk sependapat dengan saya" dan pernyataan "Saya selalu berpartisipasi dalam setiap tugas kelompok". Hal ini memperlihatkan bahwa mahasiswa Prodi Pendidikan Administrasi Perkantoran UNNES sudah mempunyai keterampilan softskill untuk bisa bekerjasama dengan orang lain dan dapat mempengaruhi orang lain.

Bukti lain dari kesiapan mahasiswa tergambar dari respon mahasiswa terhadap kemampuan menguasai perangkat perkantoran, pernyataannya yang terkait nomor delapan yaitu "Saya memiliki pengetahuan yang luas terkait dengan keilmuan yang saya tekuni saat ini" dan pernyataan nomor sembilan "Saya memiliki kemampuan mengoperasikan alat-alat perkantoran. Meskipun begitu ada yang harus dicermati dari kesiapan mahasiswa mengenai capability competency, terkait item nomor 10, yaitu "Saya hanya mampu menggunakan peralatan perkantoran yang manual dan elektronik" hanya 50\% dari sampel yang menjawab setuju, padahal kemampuan menggunakan peralatan kantor tidak hanya manual ataupun elektronik tetapi juga berbasis system/digital. Keterampilan ini harus dimiliki oleh calon tenaga kerja pada 
era MEA. Peralatan kantor digital berbasis system mengandalkan tekhnologi, seperti misalnya SIMS (Sistem Informasi Manajemen Surat) yang berfungsi untuk prosedur pengurusan surat, E-arsip dan DSS (decision support system). Digitalisasi perkantoran juga bisa berupa teleconference (pertemuan berbasis system).

Hal lain yang perlu dicermati adalah mengenai indikator kemampuan berbahasa Inggris ataupun kemampuan berbahasa lain negara-negara ASEAN, kesiapan untuk kemampuan berbahasa asing masih rendah yaitu masih dibawah 50\% dari sampel. Secara keseluruhan diukur dari capability competency yang dimiliki mahasiswa Prodi Pendidikan Administrasi Perkantoran UNNES sudah memiliki kesiapan kerja dalam menghadapi era MEA. Penelitian ini mendukung penelitian sebelumnya, yaitu penelitian Tri Harnani dan Muttanachai Suttipun bahwa capability competency termasuk didalamnya kemampuan bidang perkantoran, bersosialisasi dan berbahasa Inggris dan atau bahasa asing lainnya menjadi indikator kesiapan kerja dalam menghadapi era MEA.

\section{Knowledge competency}

Kompetensi pengetahuan dalam penelitian ini difokuskan pada kemampuan intelektual dan pemahaman mahasiswa mengenai Masyarakat Ekonomi Asean. Dari hasil penelitian menunjukan bahwa mahasiswa Prodi Administrasi Perkantoran UNNES secara keseluruhan sudah siap menghadapi persaingan kerja pada era MEA. Hal ini terlihat dari range kesiapan knowledge competency berada pada tingkat tinggi sebesar 73,14\%.

Pengetahuan seseorang mengenai satu hal akan menjadi dasar untuk melakukan suatu tindakan dan pengambilan keputusan. Hal ini mendukung penelitian Dirwanto (2008) bahwa menurutnya terdapat tujuh faktor yang mempengaruhi kesiapan kerja yaitu (1) faktor kemampuan terdiri atas variabel keterampilan, pengalaman praktik, dan kreativitas, (2) faktor citra diri terdiri atas variabel pengetahuan, penampilan diri, dan temperamen, (3) faktor pendukung terdiri atas variabel informasi pekerjaan, kondisi ekonomi keluarga, dan bimbingan vokasional, (4) faktor akademis terdiri atas variabel kedisiplinan, dan prestasi belajar, (5) faktor dasar / bawaan terdiri atas variabel nilai-nilai, keadaan fisik, dan bakat,(6) faktor perilaku terdiri atas variabel sikap, kemandirian, dan minat, dan (7) faktor cita-cita dan potensi diri terdiri atas variabel ekspektasi masuk dunia kerja, dan tingkat intelegensi. Kesimpulan yang dapat ditarik yaitu 
mahasiswa Program Studi Administrasi Perkantoran UNNES memiliki kesiapan kerja tinggi berdasarkan kompetensi pengetahuan yang dimiliki.

\section{KESIMPULAN DAN SARAN}

Kesimpulan dari penelitian ini adalah kesiapan kerja Mahasiswa prodi administrasi perkantoran Universitas Negeri Semarang dari aspek communication competency, Capability competency dan Knowledge competency sudah pada kategori tinggi, dalam arti mahasiswa jurusan manajemen sudah siap dalam menghadapi pasar bebas MEA. Meskipun masih ada keterampilanketerampilan lain yang masih harus mendapat perhatian lebih untuk disiapkan, seperti kemampuan berbahasa asing dan keterampilan dygitalisasi dalam administrasi perkantoran.

Saran yang diberikan terkait dengan hasil penelitian ialah : 1) memberikan kesempatan seluas-luasnya kepada dosen untuk lebih meningkatkan keterampilan hardskill ataupun softskill, terutama berkaitan dengan era MEA yang nantinya keterampilan tersebut akan di desiminasikan kepada mahasiswa. 2) Pemberian Pelatihan tentang Komunikasi (Public Speaking, Negosiasi dan Presentasi Bisnis) merupakan langkah strategis yang bisa ditempuh untuk membangun communication skill. 3) memfasilitasi mahasiswa dalam mengembangkan keterampilan berbahasa Inggris dan bahasa asing lainnya. 4) memberikan kesempatan seluas-luasnya kepada mahasiswa untuk mengikuti workshop atau pelatihan yang berkaitan dengan digitalisasi administrasi perkantoran, 5) melakukan kunjungan di Perusahaan-Perusahaan yang sudah mengaplikasikan perkantoran modern berbasis system yang sudah terintegrasi dengan internet, 6) Mencari informasi terkait pelatihan berbahasa asing dan pelatihan public speaking untuk menyelaraskan kemampuan berbahasa dan kemampuan berbicara di hadapan banyak orang.

\section{DAFTAR PUSTAKA}

Dirwanto. (2008) dengan judul "Analisis Faktor-Faktor yang Mempengaruhi Kesiapan Kerja Pada Siswa SMK Ma'arif NU Kesesi Kabupaten Pekalongan Tahun Pelajaran 2007/2008"

Fitriyanto, Agus. (2206). Ketidak stabilan memasuki dnusia kerja karena pendidikan. Jakarta: Dineka Cipta.

Herminanto, Sofyan. (1992). "Kesiapan Kerja Siswa STM di Jawa.” Laporan Penelitian.Yogyakarta: IKIP Yogyakarta.

Syukriah, Ana. (2013) yang berjudul Peningkatan Eksistensi Umkm Melalui Comparative Advantage Dalam Rangka Menghadapi MEA 2015 Di Temanggung. 
e-ISSN 2442-9449 Vol.5. NNo.1 (2017) 17-26

p-ISSN $2337-4721$

Tri, Hartati (2016). "Evaluasi Kesiapan

Kerja Mahasiswa Akuntansi

Universitas Negeri Yogyakarta

Menghadapi Era Masyarakat

Ekonomi ASEAN (MEA)" Hasil

Penelitian. Yogyakarta: Universitas

Negeri Yogyakarta

Undang-Undang Nomor 13 tahun 2003

tentang ketenagakerjaan 